\title{
Sesenta años de Gustavo Gutiérrez
}

\section{Revista Latinoamericana de Teología.}

Gustavo Gutiérrez es uno de los grandes renovadores de la teología en este siglo. Es un símbolo de toda una generación de télogos latinoamericanos -muchos de los cuales pertenecen al comité de redección de esta revista- que iniciaron el movimiento de la teología de la liberación; y es un teólogo que ha aportado grandemente y con la especificidad de su teologla a ese movimiento teológico.

Gustavo Gutiérrez es ante todo sf́mbolo de la teologia de la liberación, surgida alrededor de Medellín, cuyo vigésimo aniversario se celebra también en estos días. Es ésta una teología nueva en América Latina y en el mundo, porque parte de la novedosa "impción de los pobres," verdadero signo de los tiempos, en el que Dios se hace presente en los pueblos crucificados y esperanzados. Y es también una teología nueva porque se concibe a sí misma como respuesta a esos clamores y esas esperanzas. La teologia de la liberación intenta ser, por ello, una teología honrada con la realidad del continente y con lo que Dios está diciendo a través de él; una teología sacudida por los pobres y convertida a ellos. Intenta ser una teología transida de misericordia para reaccionar a sus sufrimientos y una teología que orienta e ilumina una práctica de justicia y de liberación para que la misericordia sea eficaz. Es también una teología espiritual, que quiere ser mystagogía en el misterio de Dios y propiciar el encuentro con Dios en la historia; una teología popular, voz teológica de los que no la tienen; una teología agradecida a los pobres, de cuyo pozo hay que beber y en el que se encuentra -como en el siervo sufriente de Jahvé- un tipo de luz y esperanza que no se hallan en ninguna otra parte. Es, por último, una teologfa conflictiva porque al anunciar a los pobres al Dios de la vida se confronta necesariamente con los ídolos de la muerte.

Esta teología de la liberación, en fidelidad a la impción de los pobres, se ha hecho latinoamericana y cristiana, sin que ambas dimensiones se debiliten ahora -como ha sido el caso con frecuencia- sino que se potencian. Es una teología para el pueblo de Dios; y también —en ello está cada vez más comprometida- 
del pueblo de Dios. De todo ello, junto con muchos otros, Gustavo Gutierrez es un símbolo. Pero, además, ha dado a todo ello su aporte específico.

En sus numerosos escritos ha abordado diversos temas de la toelogía de la liberacion, pero nos concentramos aqu en un solo aspecto de su teologia: en la consecuente fidelidad a aquello que la origino, los pobres de este mundo. Desde ellos Gustavo Gutiérrez ha ido eligiendo y tratando nuevos temas: el Dios de la vida, la espiritualidad, la necesidad de un lenguaje sobre Dios en un mundo sufriente, y su más reciente interés por la religiosidad de los pobres, su problemática psicológica, la realidad de la mujer oprimida, la ecología incluso, la estética... Sus nuevos intereses y sus nuevos productos teológicos no están motivados primariamente por el deseo de hacer avanzar intelectualmente a la teologia de la liberación, aunque trate esos temas con hondura intelectual y desee el perfeccionamiento de esa teologia; menos aún están motivados por pura tíctica, dada la coyuntura eclesial, como a veces se insinúa La novedad en el proceso teológico de Gustavo Gutiérrez está motivada y dirigida por los pobres de este mundo. Segín sean sus problemas y esperanzas reales, as es su teología.

Por todo ello queremos agradecer y felicitar a Gustavo Gutiérrez en sus sesenta años, y, con El, a todos los que han originado y mantienen la teología de la liberación, como teologia más latinoamericana y más cristiana, más propia del pueblo de Dios. Desde El Salvador, recordamos además con agradecimiento la solidaridad que Gustavo Gutiérrez ha mostrado con este pucblo sufriente, esperanzado y martir, como lo expresó con su presencia en el funeral de Monsefor Romero y con sus frecuentes palabras de carifio y admiración hacia él.

Como muestra de este agradecimiento encabezamos este número de la revista con su artículo Cómo hablar de Dios desde Ayacucho, problema sumamente actual, pues también hay que preguntarse como hablar de Dios desde EI Salvador - Nicaragua, desde El Libano o Sudáfrica, y problema sumamente teológico, pues, como el mismo Gustavo Gutiérrez repite, el gran problema de la teología es cómo decir a los pobres de este mundo que Dios los ama. Quizás el artículo sirva también para disipar sospechas hacia la teologia de la liberación, pues diffcilmente se puede hablar más cristiana y teologalmente. Pero habrá que recordar tamhién que Gustavo Gutiérrez y la teología de la liberación intentan hablar sobre Dios no repitiendo rutinarios conceptos, sino promoviendo la vida, la justicia y la liberación para que los pobres de este mundo puedan saber así que es verdad que Dios los quiere y qué es lo que Dios quiere para ellos. 